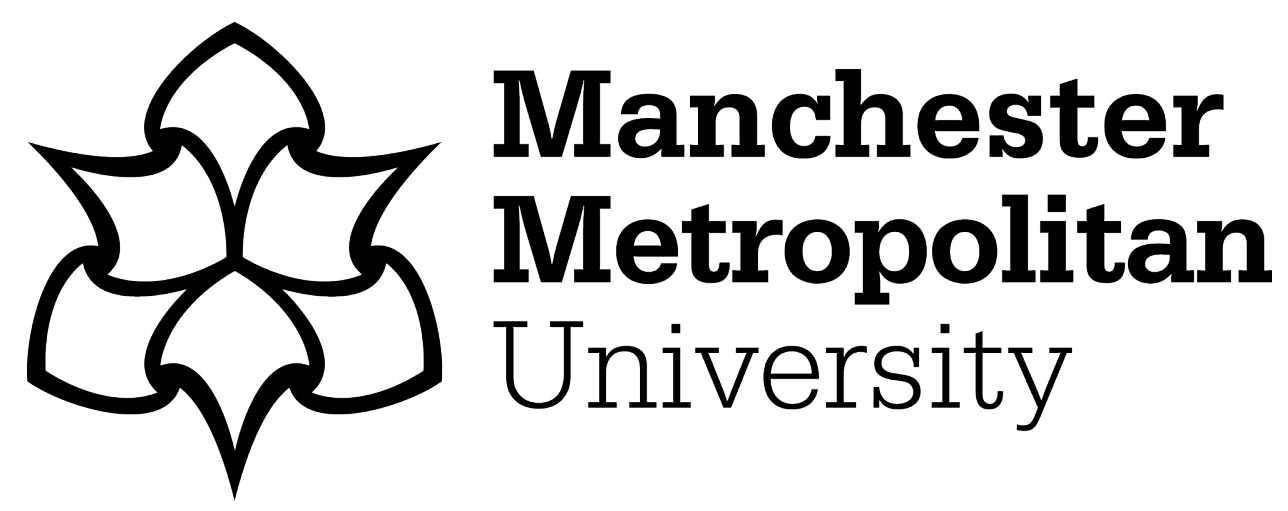

Giovanis, Eleftherios (2015) Relationship between recycling rate and air pollution: Waste management in the state of Massachusetts. Waste Management, 40. pp. 192-203. ISSN 0956-053X

Downloaded from: https://e-space.mmu.ac.uk/620968/

Version: Accepted Version

Publisher: Elsevier

DOI: https://doi.org/10.1016/j.wasman.2015.03.006

Please cite the published version 


\title{
Relationship between recycling rate and air pollution: Waste management in the State of Massachusetts
}

\author{
Eleftherios Giovanis \\ Department of Economics, Royal Holloway University of London, Egham TW20 0EX, \\ England, United Kingdom \\ Marie Skłodowska-Curie Research Fellow, University of Verona, Department of Economics, \\ Via dell'Artigliere 8, 37129 Verona, Italy
}

\begin{abstract}
This study examines the relationship between recycling rate of solid waste and air pollution using data from a waste municipality survey in the state of Massachusetts during the period 2009-2012. Two econometric approaches are applied. The first approach is a fixed effects model, while the second is a Stochastic Frontier Analysis (SFA) with fixed effects model. The advantage of the first approach is the ability of controlling for stable time invariant characteristics of the municipalities, thereby eliminating potentially large sources of bias. The second approach is applied in order to estimate the technical efficiency and rank of each municipality accordingly. The regressions control for various demographic, economic and recycling services, such as income per capita, population density, unemployment, trash services, Pay-as-you-throw (PAYT) program and meteorological data. The findings support that a negative relationship between particulate particles in the air 2.5 micrometres or less in size $\left(\mathrm{PM}_{2.5}\right)$ and recycling rate is presented. In addition, the pollution is increased with increases on income per capita up to $\$ 23,000-\$ 26,000$, while after this point income contributes positively on air quality. Finally, based on the the efficiency derived by the Stochastic Frontier Analysis (SFA) model, the municipalities which provide both drop off and curbside services for trash, food and yard waste and the PAYT program present better performance regarding the air quality.
\end{abstract}

Keywords: Air Pollution; Municipality Survey; Recycling; Solid waste services; Stochastic Frontier Analysis 


\section{Introduction}

Numerous scientific studies have linked particle pollution exposure to a variety of negative outcomes, including premature death for people with heart or lung disease, nonfatal heart attacks, irregular heartbeat, aggravated asthma, decreased lung function, and increased respiratory symptoms (Seaton et al., 1995; Nel et al., 1998; Harrison and Yin, 2000; Li et al., 2002; Li et al., 2003; Sarnat et al., 2005). However, the environmental economics literature pays attention to the waste management services cost structure rather than to the relationship between pollution, waste management and recycling. This paper proposes an econometric model to understand and describe how municipal recycling rate is associated to air pollution, and specifically to particulate matter less than 2.5 micrometers in diameter $\left(\mathrm{PM}_{2.5}\right)$. In addition, the purpose of the paper is to estimate the technical efficiency of the municipalities regarding air quality and examine which recycling and waste collection service is more efficient for air pollution reduction.

One contribution of this paper is that the analysis expands on the cross-sectional analysis of Hirsch (1965) and Bel and Fageda (2010) and relies on panel data. Firstly, by using panel data instead of only cross-sectional data which are likely lead to biased estimates due to unobservable characteristics correlated both with pollution and recycling. Panel data makes it possible to control for unobserved cross section heterogeneity, i.e. taking into account unobserved individual or time effects by including them in the model (Wooldridge, 2002). Secondly, in addition to fixed effects model, and in order to explore the technical efficiency of municipalities, this study adopts a stochastic frontier approach. Stochastic frontier production functions postulate the existence of technical inefficiencies of production for municipalities involved in producing a particular output (Battese and Coelli, 1995), which is the air quality (or equivalently air pollution) in this case. In the majority of the literature, 
stochastic frontier models are estimated with cross-sectional data. In this regard, the innovation introduced by this work is that it applies stochastic panel models to evaluate the efficiency of municipalities concerning the recycling rates. The structure of the paper is as follows. The second section presents the literature review. It reviews theoretical and empirical studies on solid waste management using various approaches including stochastic frontier analysis and data envelopment analysis. Section three presents the data; section four discusses methodology used in the analysis of solid waste services. In section 5 the materials and methods used in this study are described, while in section six the empirical results and recommendations are reported and discussed. In section six the conclusions are presented.

\section{Literature review}

Previous studies examined the relationship between recycling, air pollution and recycling programs. However, this study contributes to the literature by investigating the relationship between recycling and air pollution, controlling for various economic, demographic and trash collection and recycling programs.

In this study the PAYT program effects on air pollutions are examined. Russell (2011) examined the recycling in the state of Massachusetts and found that the type of collection, curbside, drop-off, single-stream, or pay-as-you-throw (PAYT), has an impact on the success of the recycling program. PAYT and single-stream systems were shown to increase recycling rates, while the residents who live in towns with drop-off programs actually recycle more material than those in towns with curbside service. The characteristics of these programs are discussed in more details in the methodology part. Kuhn and Schulz (2003) found that environmental quality is negatively affected by the amount of waste dumped and the amount of resources extracted. In addition, the authors show that balanced sustainable growth is only possible if governmental policy ensures a recycling rate of 100\%. Samakovlis (2001) employs a dynamic general equilibrium growth model and found that before a waste management 
hierarchy can be established, it is important to focus on total allocative efficiency rather than just on material recycling per se. Merrild et al, (2012) found that the environmental benefits are higher when recycling paper, glass, steel and aluminium instead of incinerating it.

In this study the Stochastic Frontier Analysis (SFA) also is examined in order to estimate the recycling technical efficiency of each municipality. SFA applications to Municipal Solid Waste (MSW) services have been scarce so far. De Groot (2011) examined the cost efficiency of waste management of Dutch municipalities for the period 2005-2008. He found that contracting out seems to imply cost savings, but ownership of the suppliers, either public or private, hardly matters. In addition, economies of scale do not exist, except for the smallest municipalities. Afonso and Fernandes (2008) measure the relative efficiency of Portuguese municipalities in a non-parametric framework approach using data envelopment analysis. Their results suggest that most municipalities could achieve the same level of output using fewer resources, indicating that they are technically inefficient.

Generally, previous studies found that recycling rate and income per capita have a positive effect on air quality, while trash has negative impact Fishbein, 1991; Grossman and Krueger, 1993; 1995; Carson et al., 1997; Panayotou, 1997, Verneke and Clercq, 2006; Wiedinmyer et al., 2014). Moreover, PAYT encourages the recycling with further effects on air quality improvement (Bilitewski, 2008; Reichenbach, 2008). Callan and Thomas (1997) found that PAYT programs in combination with curbside recycling strongly influence recycling rate. They find unit based pricing increases recycling 6.6 percentage points and when used in combination with curbside recycling service it increases recycling 12.1 percentage points. However, Callan and Thomas (1997) point out that the downside to unit pricing is it may encourage illegal disposal or burning; therefore offering free curbside recycling services is a way to offset the illegal disposal of recyclables. 


\section{Data}

In this section the data sample is described. The reason why the data are initially presented is that it will be easier for the methodology part to be understood. $\mathrm{PM}_{2.5}$ is one of the six most common air pollutants including $\mathrm{CO}, \mathrm{SO}_{2}, \mathrm{NO}_{\mathrm{X}}$, Lead and Ground-Level Ozone. The paper focuses on $\mathrm{PM}_{2.5}$ as it is better monitored than other pollutants (7 monitoring stations) throughout the state of Massachusetts, for which this analysis is done (21 stations). Data on recycling is obtained for 325 municipalities and cities in the state of Massachusetts from municipality surveys during the period 2009-2012.

The data used in this study come from various sources. More specifically, the solid waste municipality survey, the recycling rates and the air pollution data for $\mathrm{PM}_{2.5}$ can be found at the Massachusetts Department of Environmental Protection website (http://www.mass.gov/eea/agencies/massdep/) for the period 2009-2012. $\mathrm{PM}_{2.5}$ is measured as the average pollution over a yearly period.

The municipal solid waste (MSW) recycling rate is calculated by the Massachusetts Department of Environmental Protection as:

$$
M S W \text { recyclingrate }=\frac{\text { Total } M S W \text { recycled }}{\text { Total } M S W \text { generated }}
$$

, where Total MSW generated $=$ MSW recycled + MSW disposed as trash. This ratio is calculated separately for different product but especially hazardous products, like batteries, computers and electronic equipment, and conversion factors are used to convert values into lbs, so that they can be aggregated.

Particulate matter $\left(\mathrm{PM}_{2.5}\right)$ is a complex mixture of extremely small particles and liquid droplets. Particle pollution is made up of a number of components, including acids (such as 
nitrates and sulfates), organic chemicals, metals, and soil or dust particles. $\mathrm{PM}_{2.5}$ or "Fine particles", such as those found in smoke and haze, are 2.5 micrometers in diameter and smaller. These particles can be directly emitted from sources such as forest fires, landfills, waste disposal, combustion-incineration processes or they can form when gases emitted from power plants, industries and automobiles react in the air.PM 2.5 is measure in Micrograms per Cubic Meter of Air $\left(\mu \mathrm{g} / \mathrm{m}^{3}\right)$.This study will focus on $\mathrm{PM}_{2.5}$. Regarding mapping $\mathrm{PM}_{2.5}$ to each municipality the following approach is followed. Firstly, the exact location of each monitoring station in terms of longitude and latitude coordinates is found. Secondly, the centroid coordinates of each municipality is given. The next step is to compute the nearest neighbours using geodetic distances, and specifically the Haversine formula (Robusto, 1957) and matching each monitoring station to the closest centroid without imposing any restriction on how far from a monitoring station the municipality can be. In addition, it should be noticed that the results for specific distance between municipality and monitoring station ie. within 10 or 20 miles show the same negative relationship between recycling and air pollution; however the effects become stronger as long as a municipality is located closer to a monitoring station. Next the economic and demographic variables are described.

The population density has been retrieved from the Massachusetts Executive Office for Administration and Finance. The income per capita for each municipality comes from the Massachusetts Department of Revenue (DOR), while the unemployment rates have been retrieved from the Massachusetts Executive Office of Labor and Workforce Development. The meteorological data-average, minimum and maximum temperature, wind speed and precipitation- can be found at Tutiempo weather and the US National Climatic Data Center (NCDC). The study period is 2010-2011 and the data are based on yearly frequency. Note, no day above the threshold triggering a smog alert was reported during the period examined. It should be noted, that the traffic volume counts could have been used, but the data are available only up to 2009. More specifically, the variables included in the model are: 
Population Density. This variable is derived by dividing the municipality population, which is included by itself, by the land area size. The second variable is the Income per capita for each municipality. The sign might be positive, as a higher income implies higher consumption and additional waste and pollution. However, based on the Environmental Kuznets Curve (EKC) hypothesis the relationship between air pollution and income can be an inverted Ushaped curve. Unemployment rate in each municipality is another variable used in the analysis. This should be negative as a higher unemployment rate implies less purchasing power; therefore less waste volume, as well as, less air emissions caused by transportation to work.

The next two variables are the Reciprocal and Regional Program: The former is a dummy taking the value 1 if there is a reciprocal program in the municipality and 0 otherwise. More precisely, this program refers to a reciprocal use agreement with other municipalities to allow their residents to deliver waste and problem materials to the municipality's permanent facilities and event collection sites. Similarly, Regional program is a dummy taking the value 1 if there is a regional program in the municipality and 0 otherwise However, these variables are potentially endogenous. For this reason, initially the model is estimated without the potential endogenous variables and then including all of them. The next variables refer to trash, yard and food waste service types, which are categorical variables. Trash takes three values 1 if there is only drop off service, 2 if only curbside service is available and 3 if both drop off and curbside services are available. Similarly, variables yard and food waste service types take four values; 1 if both drop off and curbside services are available, 2 if there is a drop off service only, 3 if there is curbside service only and 4 neither of the above. In a curbside recycling program, recyclable materials, such as cans and bottles, are placed in special containers at the curb for pickup by a recycling truck. A drop off recycling program provides a centre where citizens can transport and drop off their recyclable materials. Where appropriate, the index of these variables is: 1 for curbside, 2 for drop-off and 3 if there are 
both services and 4 for none of the above. Because reciprocal and regional program, as well as, trash, food and yard waste service type are possibly endogenous the estimates take place without and with them. Meteorological data are considered in the analysis too. It is expected that $\mathrm{PM}_{2.5}$ is negatively associated to minimum temperature, precipitation and wind speed, while a positive sign is expected for average and maximum temperature (Tai et al., 2010; Barmpadimos et al., 2012; Lecoeur et al., 2012; Tai et al., 2012). We obtain the average values over a year of the above meteorological variables. Combustion, is a dummy variable taking value 1 if there is a combustion-incineration plant in the municipality and 0 otherwise. It should be noticed that the incineration process is not considered as recycling, but is a process which is used to minimise the generation of wastes and reduce landfilling. This variable is taken into consideration, because incinerators are one of the major sources of $\mathrm{PM}_{2.5}$ in Massachusetts (Massachusetts Department of Public Health, http://www.mass.gov/eohhs/gov/departments/dph/).

Landfill is a categorical variable taking four values; 1 for no-landfill in the specific municipality, 2 if both are private, 3 if one is private and 4 if both are public. This is measured to examine which regime-public or private- is more efficient in generating air quality, as in the literature used to examine the efficiency of waste management service costs (Hirsch (1965; Kemper and Quigley, 1976; Collins and Downes, 1977; Bel and Fageda, 2010). Municipality Type is a dummy variable indicating whether the municipality is a city or a town. The distinction between a city and a town as defined in Massachusetts law is primarily related to the form of government that the municipality has chosen. More specifically, a town is governed under the Town Meeting or Representative Town Meeting form of government. A city has a council or board of aldermen and may or may not have a mayor, a city manager, or both (State Street Trust Company, 1922). Finally, PAYT is considered in the analysis, which is a dummy variable taking value 1 if there is PAYT (Pay-as-you-throw) program and 0 otherwise. In these program residents are charged for each community-issued bag or container 
of waste they set out for disposal, and the residents have a variety of bag and container sizes from which to choose. Next the summary statistics and the pairwise correlations between the variables are discussed.

In Table 1, summary statistics separately for every year are reported after reweighting municipalities by their population size. The average recycling rate has increased by 3 percentage points from 2009 to 2012, while the average air pollution $\left(\mathrm{PM}_{2.5}\right)$ decreased from 2009 to 2012 by $12 \%$. In addition, the income per capita and unemployment rate have increased and decreased respectively from 2009 to 2012. In Figure 1 a locally weighted scatter-plot smoothing, which is a non-parametric regression, is presented. Figure 1 shows the relationship between $\mathrm{PM}_{2.5}$ and recycling rates, indicating a negative association. In addition, an outlier is observed in the right side of Figure 1, was excluded, but this does alter the conclusion. It is decided to keep this outlier. It should be noticed that the change in coefficients are considerable very small ie. the coefficient of recycling rate on air pollution is -0.0210 without the outlier, while it becomes -0.0211 including the outlier

In Table 2 the correlation matrix is presented. The correlation between total trash tonnage and $\mathrm{PM}_{2.5}$ is positive but statistically insignificant. The correlation between population density and total trash tonnage is positive. Therefore, one assumption is that the higher the population density the higher the trash tonnage might be and so the higher the air pollution is expected to be from waste generation and landfilling depending on the recycling rates and traffic density among other factors. In addition, the relationship between population density, recycling rates and income per capita is negative, indicating that the higher the population density is the lower the recycling rates and income are expected to be. Therefore, as the income rises the population growth rates go down.

The income per capita is negatively correlated with air pollution and total trash tonnage and its relationship with recycling rate is positive, indicating that high income municipalities 
contribute in a positive way on recycling and air quality. This indicates that the rising income brings population growth rates down, therefore population pressure on the environment decreases. One explanation is that as the economic development progresses the share of industry is reduced, while the share of services is increased. More specifically increased economic growth triggers a composition shift of economic activity away from heavy manufacturing to services, and that economic growth may also generate environmental benefits through the development and adoption of new technology as the adoption of cleaner production processes and improved energy efficiency. In addition the income elasticity of demand for environmental quality is greater than zero, as the environmental quality is often considered as normal good if not luxury. Therefore, as income grows environmental concern rises as well (Beckerman, 1992).

The total trash tonnage and $\mathrm{PM}_{2.5}$ negatively and significantly correlated with recycling rate and the association is significant. Therefore, the higher the recycling rate is, the lower the air pollution is expected to be. This negative correlation can be explained by various facts. Firstly, the lower recycling rates imply more waste generated which is led to landfills or incinerators. In fact the burnt waste, through incinerators, is transformed into ashes and gas. As this happens, chemical reactions lead to the formation of hundreds of new compounds, some of which are extremely toxic. The number of substances released from a waste incinerator may run into thousands. So far, scientists have identified a few hundred substances as hazardous (De Fre and Wevers, 1998; Knox, 2000). In addition, incinerators are inefficient at generating electricity from burning waste, and recycling and composting conserve three to five times more energy than is produced by incinerating waste (Global Alliance for Incinerator Alternatives, 2009). Regarding landfills, lower recycling rates imply higher volume of waste led to landfills. Garbage causes many pollution problems and when piles of garbage sitting in one area for years are mixed with different chemicals and weather conditions, it can be fatal to the environment and to health (EPA, 1995). Finally, 
unemployment rate is negatively correlated with $\mathrm{PM}_{2.5}$ and total trash tonnage and recycling rate, while its association with the income per capita tonnage is negative and significant in all cases.

\section{Econometric framework}

\subsection{Fixed effects}

Initially the following fixed effects model is estimated:

$$
\ln p m_{i j t}=\beta_{0}+\beta_{1} \ln r e c \_r a t e{ }_{i t}+\gamma_{z}{ }^{\prime} \ln W_{i t}+\delta_{z}{ }^{\prime} X_{i t}+\mu_{i}+l_{j}+\theta_{t}+\varepsilon_{i j t}
$$

, where variable $p m$ is the $\mathrm{PM}_{2.5}$ emissions, rec_rate is the recycling rate, subscript $i$ represents the municipality, subscript $j$ denotes the air pollution monitoring site for $\mathrm{PM}_{2.5}$ and subscript $t$ indicates the year. Vector $W$ includes meteorological variables as minimum, maximum and average temperature, precipitation and wind speed. Vector $X$ includes the additional factors presented in the data section (note all the quantitative variables are expressed in logarithms). Finally, the vector $\mu_{i}$ includes municipality dummy variables, while $l_{j}$ and $\theta_{t}$ control for air pollution monitoring stations and year fixed effects respectively. Based on Hausman test the fixed effects over the random effects model is chosen.

Through this framework this study aims to provide a detailed empirical analysis of the factors that determine air pollution levels through waste services, like curbside, drop-off, and meteorological data. More specifically, many factors contribute to the success of municipal recycling programs, both demographic as well as the type of program in place. There are several different types of recycling programs a town can implement, such as a curbside program, Pay-As-You-Throw (PAYT), or single stream program. Demographic factors, including population density, income, unemployment rate and location might have an impact on the local recycling rate and the air pollution. 
In addition, a quadratic function of income per capita is included as in Grossman and Krueger (1993; 1995), Panayotou (1997) and Verneke and Clercq (2006) who examined the Environmental Kuznets Curve (EKC) hypothesis- which explores the relationship between air pollution and income- and found an inverted U-shaped curve, indicating that the positive relationship between air emissions and income is inverted after a given point of income. By studying all of these different factors, this study looks to determine what actions can be taken by towns to increase their residential recycling rates and improve air quality.

\subsection{Stochastic Frontier Analysis (SFA)}

The next proposed model is a stochastic frontier analysis (SFA). The stochastic production frontier (Aigner et al., 1977; Battese and Corra, 1977; Meeusen and van den Broeck, 1977; Battese and Coelli, 1995) is motivated by the idea to assess how far each municipality allocation from the efficiency frontier is. These models allow for technical inefficiency, but they also acknowledge the fact that random shock outside the control of producers can affect output. They account for measurement error and other factors, such as effects of weather, luck, etc., on the value of the output variable, together with the combined effects of unspecified input variables in the production function. The stochastic frontier model (Battese and Coelli, 1995) may be written as:

$$
\begin{aligned}
& \text { ln } \mathrm{pm}_{i j t}=a_{i}+\beta_{1} \text { lnrec_rate }_{i t}+f\left(\gamma z_{i t}\right)+V_{i j t} \pm U_{i j t} \\
& \text {, for } i=1, \ldots, N, j=1, \ldots, K, t=1, \ldots T
\end{aligned}
$$

, where Inpm $_{i j t}$ and lnrec_rate is the air pollution and recycling rate respectively expressed in logs as in (2), while $z_{i t}$ contains all the independent variables in (2). The function $f(\bullet)$ denotes the functional form. The error term is comprised of two separate parts. $V_{i j t}$ are random variables assumed to be identically and independently distributed (iid) $\mathrm{N}\left(0, \sigma \mathrm{v}^{2}\right)$, and independent from $U_{i j t . .}$ The $U_{i j t}$ are non-negative random variables which are assumed to 
account for technical inefficiency in production or the cost of inefficiency in production and are assumed to be iid $\mathrm{N}\left(\mathrm{mu}, \sigma_{\mathrm{u}}{ }^{2}\right)$, where its sign depends on whether the frontier describes costs (positive) or production (negative). In the case examined $U_{i j t}$ is positive, as air pollution is considered a cost and shocks will push the air pollution level above the efficiency frontier. In addition, three parameters are included in SFA, mu $(m)$, gamma $(g)$, and eta $(h)$.The mu ( $m$ ) parameter determines the distribution the inefficiency effects have, either a half-normal, or truncated normal distribution which is defined respectively as (Kumbhakar and Lovell, 1990):

$$
\begin{aligned}
& m_{\text {half-normal }}=\sigma_{v}^{2}+[1-2 / \pi] \sigma_{u}^{2} \\
& m_{\text {truncated normal }}=\mu^{2} \frac{\alpha}{2}\left(1-\frac{\alpha}{2}\right)+\frac{\alpha}{2}\left(\frac{\pi-\alpha}{\pi}\right) \sigma_{u}^{2}+\sigma_{v}^{2}
\end{aligned}
$$

, where $\alpha=\left[\Phi\left(\mu / \sigma_{\mathrm{u}}\right)\right]^{-1}$ and $\mu$ is a replacement parameter, which is allowed to be negative, zero or positive. The gamma parameter is the variance-ratio parameter, and is important in determining whether a stochastic production frontier is explained by heterogeneous inefficiency. Specifically, the average production function has a gamma value of zero, meaning that there is no technical inefficiency $(U i)$, or in other words, municipalities are operating at full capacity. Where the value of gamma is one, the full-frontier model is chosen. The gamma parameter is defined as:

$$
g=\sigma_{u}^{2} /\left(\sigma_{v}^{2}+\sigma_{u}^{2}\right)
$$

The eta $(h)$ parameter is the parameter that determines whether the inefficiencies are timevarying or time invariant. An eta parameter value that is significantly different from zero indicates time-varying inefficiencies, while a value not significantly different from zero indicates time invariant inefficiencies. The initial results from the SFA with random effects model by Battese and Coelli (1995) present a value of gamma ( $g$ ) parameter close to one and 
significant value for eta $(h)$ parameter indicating time-varying inefficiencies However, the results for the SFA with random effects are not reported as they are very close to those derived from the SFA with fixed effects, similarly to other studies. Kumbhakar (1990) specified eta as the following parametric function of time:

$$
e t a=\left[1+\exp \left\{\varkappa t+\delta t^{2}\right\}\right]^{-1}
$$

, where $t$ is a set of time dummy variables, $\gamma$ and $\delta$ are parameters to be estimated. The hypothesis of time-invariant technical efficiency can be tested by testing the hypothesis that $\gamma=\delta=0$. The measure of efficiency in the stochastic production frontier model is defined as (Coelli, 1996):

$T E_{i j t}=\exp \left(-U_{i j t}\right)$

, where the Technical Efficiency (TE) in this case takes a value between zero and one. In addition $U_{i j t}$ are assumed to be independently distributed as truncations at zero of the $\mathrm{N}\left(\mathrm{m}_{\mathrm{it}}, \sigma_{\mathrm{U}}^{2}\right)$ distribution. $m_{i t}=z_{i t} \delta$, where $z_{i t}$ is a $p \times 1$ vector of variables which may influence the efficiency of municipality; and $\delta$ is an $1 \times p$ vector of parameters to be estimated.

\section{Materials and Methods}

In this section the origin of the recycling data is discussed. In addition, the econometric framework followed in this study is described and the main reasons why this methodology can be appropriate are discussed. Finally, the limitations of the econometric methodology are presented. 
Firstly, information of the origin of solid wastes and a brief description of methodology converting different types of material in weight is discussed and reported in tables 3-4. Table 3 shows what the sources of waste are. More specifically, waste comes from households, including various materials and products, such as paper, metal and household hazardous products. The sources include industry and commercial places, institutions, as schools and municipal services like water and parks. Finally, manufacturing, construction and agriculture are other possible sources of waste generation. In table 4 the conversion factors of volume of specific products and material into weight are reported. Then based on these conversion factors, using equation (1) the recycling rate is calculated.

Next the methodology followed in this study is discussed. Fixed effects regressions are very important because data often fall into categories such as industries, states and household among others, while in the case examined the unit is the municipality. By including fixed effects (group dummies for municipalities), the average differences across municipalities in any observable or unobservable predictors are controlled. These differences can include traffic, industrial activity, vanpooling and other factors t might affect the dependent variableair pollution emissions. If the regressions are estimated with plain ordinary least squares (OLS) then there is a great worry that omitted variable bias would result because unobservable factors can be correlated with the variables that are included in the regression. The fixed effect coefficients soak up all the across-group action. What is left over is the within-group action, which is what is desirable and the threat of omitted variable bias has been reduced a lot. Therefore if equations (2) and (3) are the true models, then estimating them using the standard OLS method with a single constant $\alpha$ will lead to biased estimates of the parameters and inefficiencies. In Fig. 2, the four parallel lines represent the cost function as fitted by the panel data estimator and the single line with a different slope represents the cross-section estimator with a single constant term. Output denotes thee air pollution and inputs the right hand variables in regression models. In addition, $P M$ in Fig. 2 expresses 
particulate matter examined in this study, while for simplicity $X$ represents a specific input. The circled clusters of $X s$ represent observations on each municipality in different years. From the way the figure is drawn, it is clear that the relationship between output (air pollution) and inputs (ie the slope $\varphi$ ) is the same for all municipalities but that the constants $(\alpha)$ are different, reflecting persistent, unobserved differences across municipalities. Thus, when the constant is constrained to be the same across municipalities, the resulting function slope is biased.

Regarding the fixed and random effects approaches each have virtues and shortcomings. The fixed effects estimator is distribution free. However, this model assumes a common technology/frontier encompassing every sample observation. This may be inappropriate in the sense that the estimated technology is not likely to represent the "true" technology for all observations (Farsi et al., 2006). Time invariant effects in the model are also dropped out in this framework. The random effects model has a tighter parameterization which allows direct municipality specific estimates of the inefficiency term in the model. However, the random effects model rests on the strong assumptions that the effects are time invariant and uncorrelated with the variables included in the model. Another drawback of fixed effects models is that they require the estimation of a parameter for each unit the coefficient on the unit dummy variable, which in the case examined is the municipality. This can substantially reduce the model's power and increase the standard errors of the coefficient estimates.

The next part discusses the SFA modeling and why this can be a proper method in the case examined, as well as, what are the additional advantages over the simple fixed effects model. Farrell (1957) examined the measurement of productive efficiency and he proposed a stimulating idea to define output of the most efficient firms or any kind of organization or municipality as the production frontier for all firms as opposed to the neoclassical theory that assumed all firms to be fully efficient in their use of technology. For simplification and 
presentation reasons the basic idea underlying the Farrell approach to measuring efficiency is illustrated in Fig. 3. Based on Farrell let's consider a municipality that employs two inputs of increasing the air quality output (or equivalently reducing the air pollution output). Two inputs are considered for simplicity and graph representations reasons. For example input 1 $\left(\mathrm{x}_{1}\right)$ represents recycling and input $2\left(\mathrm{x}_{2}\right)$ represents PAYT program. These assumptions make it possible to illustrate the air quality function by a simple isoquant diagram, designated by $\mathrm{y}^{\mathrm{o}} \mathrm{y}^{\mathrm{o}}$ in Fig. 2. The point $\mathrm{P}$ represents the units of two factors, per unit of output that the municipality is observed to use. The isoquant $\mathrm{y}^{\mathrm{o}} \mathrm{y}^{\mathrm{o}}$ represents various combinations of the two factors that a perfectly efficient municipality might use to produce a unit output. It is also important to note that $\mathrm{y}^{\mathrm{o}} \mathrm{y}^{\mathrm{o}}$ presents a lower bound of a scatter indicating the same level of output and as such $\mathrm{Q}$ and $\mathrm{P}$ are on the same isoquant. The point $\mathrm{Q}$ represents an efficient municipality using the two factors in the same ratio as P. It can be seen that it produces the same output as $\mathrm{P}$ using only a fraction $\mathrm{OQ} / \mathrm{OP}$ as much of each factor. It is producing $\mathrm{OP} / \mathrm{OQ}$ times as much output from the same inputs. Therefore OQ/OP is defined as the technical efficiency of municipality P. The technical inefficiency of that municipality is presented by the distance QP which is the amount by which all inputs could be proportionally reduced without a reduction in outputs. The municipality is technically efficient if the ratio is equal to 1. If the ratio is less than 1 the municipality is inefficient. Price or allocative efficiency of the municipality can be measured from Fig. 3. This measures the extent to which a municipality uses the various factors of in the best proportions, in view of their prices. Considering the budget line represented by FG, its slope is equal to the ratio of the prices of the two factors of production. Therefore the optimal point is obtained where the isoquant curve is tangential to the budget line and that is point Q. At this point the municipality is both technically and allocativelly efficient. The allocative efficiency is the fraction OR/OQ. However, in this study only the technical efficiency is examined, as the information on prices necessary for exploring the allocative efficiency is not available. 


\section{Empirical results}

In Table 5 the fixed effects and SFA estimates are reported. Based on Hausman test the fixed effects model is chosen. The results suggest that the increase on recycling rates is associated with decrease on $\mathrm{PM}_{2.5}$ and it is statistically significant at 1 and 5 per cent respectively for fixed effects and SFA fixed effects models.

The income per capita is reported in quadratic terms, since higher polynomial orders have been found insignificant. We find an inverted U-shaped curve of the relationship between income per capita and pollution, similar to other studies (Grossman and Krueger, 1993; 1995, Panayotou, 1997, Verneke and Clercq, 2006). More specifically, the turning points range between $\$ 23,000-\$ 26,000$ average municipal income. This indicates that the initial increases on income are associated with higher levels of air pollution; however after some point, which is $\$ 23,000-\$ 26,000$ based on fixed effects and SFA fixed effects estimates, the air pollution is decreases with additional increases on income. This can be explained by the fact that higher income is associated with higher education level, environmental awareness and information, which leads to individual, household and industrial recycling, the reduction on traffic through usage of public transit, vanpooling and carpooling and to consumption of hybrid cars among other practices. Shafik and Bandyopadhyay (1992) found that the turning points for sulphur dioxide and carbon monoxide emissions range between $\$ 2,200$ and $\$ 14,400$ in 2009 prices. Selden and Song (1994) estimated EKCs for sulphur dioxide, nitrogen oxides and carbon monoxide using longitudinal data on emissions in developed countries. They found turning points of $\$ 17,300$ for sulphur dioxide, $\$ 22,300$ for nitrogen oxides, and $\$ 11,100$ for CO in 2009 prices. Grossman and Krueger (1993) report turning points equal at $\$ 8,900$ and $\$ 11,060$ in 2009 prices for sulphur dioxide and nitrogen oxides respectively using data from the Global Environmental Monitoring System (GEMS) in 126 cities in 74 countries. 
Unemployment rate has a positive effect on air quality, while a quadratic term was tested but was never significant. Similarly, for population density, the quadratic term was, as in other studies (Skene et al., 2010; Clark et al. 2011) not significant; therefore only the linear term is considered. The results show that population density leads to reduced air pollution. Regional transportation plans, public officials, and urban planners have been seeking to densify urban areas, using strategies referred to as "smart growth" or "livability." They have claimed that densifying urban areas would lead to lower levels of air pollution, principally because it is believed to reduce travel by car.

From Table 5 the PAYT seems to have a positive impact on air quality. It should be noted that the average recycling rate in municipalities where the PAYT system is implemented is 33.75 per cent, much higher than in municipalities with no PAYT system (25.68\%). PAYT is seems that it has a positive impact on air quality and it is statistically significant 1 per cent.

Regarding the geographical effects, towns and municipalities located in the western part of the state have lower air pollution concentration levels. In addition, when waste landfills are public or one of them is private, the air quality is improved. Studying the characteristics in specific municipalities, considering additional factors, as the distance between municipality and the air monitoring station and meteorological data among others, can be helpful in order to design the appropriate trash collection and recycling processes.

Based on the results of table 5 and SFA model and using relation (20) the technical efficiency scores are calculated and presented in Fig. 4 with mean, minimum and maximum values equal at $0.903,0.558$ and 0.984 respectively. The average value shows that the average technical efficiency of municipalities is very high and close to 1 . However, there are still municipalities that present a low technical efficiency indicating that some municipalities are still using their resources inefficiently in the recycling process and there still exists opportunities for improving on their current level of technical efficiency. The income per 
capita and recycling rate are significant factors for improving efficiency, while unemployment rate is contributing negatively. Moreover based on the estimates of tables 5 PAYT programs and the availability of both drop off and curbside services for trash, food and yard collection can improve the efficiency of a municipality's recycling process. Thus, municipalities can reduce the air pollution by 10 per cent on average.

Generally the results are consistent with previous studies. Regarding, recycling the results show that an increase on recycling rates will lead to decrease of air pollution. This can be explained by the fact that there is less trash volume on landfills and rarer combustion processes which emit air pollutants. This is confirmed also by the negative impact of trash tonnage in table 5. Moreover, as Fishbein (1991) states the main objectives of recycling and repackaging are two folds. Social benefits, which can be referred to as environmental and economic benefits, which are savings in virgin raw material, reduced energy and water consumption thereby reducing air, land and water pollution.

The total trash tonnage has a positive sign to air pollution and is significant in both estimates at 5 per cent level. The positive association between trash and air pollution is explained by the fact that trash gathered on landfills emit air pollutants. Furthermore, most of the trash if not recycled is led for burning and combusting processes (Wiedinmyer et al., 2014). The study by Wiedinmyer et al. (2014) concluded that the trash fires produce emissions equivalent to as much as 29 per cent of officially reported human-related global emissions of small particulates (less than 2.5 microns in diameter), as well as 10 per cent of mercury and 64 per cent of a group of gases known as polycyclic aromatic hydrocarbons (PAHs). These pollutants have been linked to such significant health impacts as decreased lung function, neurological disorders, cancer, and heart attacks.

Regarding population density Skene et al. (2010) found a significant relationship between population density and air quality using linear term of the former. Population density reduces 
air pollution as in densifying urban areas the travel by car is reduced and individuals use more public transit, as well as, vanpooling and carpooling (Carson et al., 1997; Clark et al. 2011; Giovanis, 2014). The argument of controlling for population density is that the government may be forced to adopt stricter pollution control regulations when more people are exposed. Since income levels generally rise with population density and urbanization in the United States, the income-pollution relationship may simply be a consequence of the population density over the urbanization effect (Carson et al., 1997). Population density is significant at 5 and 1 per cent levels based on fixed effects and SFA fixed effects models respectively. Moreover the results indicate that population density increase so recycling rate is increased because denser areas have more recyclables per square mile and thus will be more attractive markets for recycling companies Callan and Thomas (1997).

Regarding income per capita, an inverted U-shaped curve between income per capita and pollution, similar to other studies (Grossman and Krueger, 1993; 1995, Panayotou, 1997, Verneke and Clercq, 2006) is found. The linear term of income per capita is statistically significant at 1 per cent, while the quadratic term is significant at 5 per cent in both models. The results also confirm the study by Carson et al. (1997), where the authors examined seven types of air emissions-including air toxics, greenhouse gases, carbon monoxide (CO), nitrogen oxides $\left(\mathrm{NO}_{\mathrm{X}}\right)$, sulphur dioxide $\left(\mathrm{SO}_{2}\right)$, particulate matter $\left(\mathrm{PM}_{10}\right)$ and volcanic organic compounds (VOC)- across the 50 US states and find all seven pollutants decrease with increasing per capita income.

Concerning trash collection service drop off seems to be more efficient on air quality improvement than curbside service is. More specifically, trash collection service is a categorical variable taking three values: 1 if there is only drop off service, 2 whether there is only curbside service and 3 if there are both services. The results in table 5 are reported only for categories 2 and 3, while category 1 is the reference which is excluded from the regression 
analysis because of the multicollinearity problem. The coefficients of curbside service and the availability of both services are respectively -0.0199 and -0.196 . However, interpreting a dummy variable's coefficient when the dependent variable has been logtransformed, as in this case, has to be undertaken with care (Wooldridge, 2002). Therefore, the effect becomes $\exp (\beta)-1$, where $\beta$ represents every time the dummy coefficient. Therefore the air pollution is less by -0.0197 and -0.178 when only curbside service is available and both services are available than when only drop off service is available. Moreover, the higher coefficient -0.196 shows that the air quality is improved more when both curbside and drop off services are available. The coefficients are significant at 1 per cent level with the exception category 2 and fixed effects model. Similarly, the results for food and yard collection services show that the air quality is improved more when both drop off and curbside services are available. More specifically, when both services are available the air pollution is reduced by 0.048 and 0.0157 based on fixed effects and SFA model, while the air pollution is higher when only drop off service is available in comparison with no available service. This indicates the air pollution coming from trash transportation and the limitations of recycling services using this option. This indicates the benefits of using both services. Dropoff centres are commonly used in areas where individual household collection is impractical and cost savings are important. Additional, Advantages of drop-off centres are their low capital costs, ease in collecting more categories of materials than is practical with curbside collection and lack of need for staffing. However, drop-off centres are less convenient than curbside pickup, and as a result a lower volume of materials is usually recovered. Also, recyclables can be contaminated with unacceptable items; they are vulnerable to theft, vandalism, and litter; and they can become unsightly if not staffed. The convenience of curbside collection results in a higher recovery rate than can be achieved with drop-off centres, and collection can be consolidated with solid waste pickup. However, curbside collection involves higher equipment and operating costs, it is labour intensive, and it is a 
more complex process to manage. Nevertheless, the results indicate that when both services are available air quality is improved.

Concerning the meteorological data all the coefficients present the expected signs and are significant at 1 and 5 per cent level. The strongest negative effects on air quality are presented from maximum temperature, while minimum temperature has the strongest positive impact on air quality followed by wind speed and precipitation. The results are consistent with other studies, where higher levels of temperature are associated with higher levels of air pollution, while on the contrary precipitation and wind speed through clean washing process have positive effects on air quality (Tai et al., 2010; Barmpadimos et al., 2012; Lecoeur et al., 2012; Tai et al., 2012). The temperature could play a significant role in the toxicity of certain air pollutants (Gordon, 2003). Furthermore, several studies have identified that stronger pollution effects exist during higher temperature levels. (Peng, et al., 2005; Park et al., 2010).

As it was mentioned before, PAYT program has a positive effect on air quality. In PAYT programs, residents are charged for each community-issued bag or container of waste they set out for disposal, and the residents have a variety of bag and container sizes from which to choose. It should be noticed that the average recycling rate in municipalities where the PAYT system is implemented is 33.75 per cent, far away higher than the municipalities' recycling rate with no PAYT system, which is 25.68 per cent. According to a study released recently by the New York-based Green Waste Solutions and the U.S. Environmental Protection Agency (EPA, 2010) local governments with PAYT programs produce 467 pounds of landfilled trash per capita per year, compared with 918 pounds in non-PAYT communities. In Massachusetts, cities and towns with PAYT programs produce approximately 0.56 tons of trash per household compared to 1.13 tons for non-PAYT communities. In addition, PAYT can be applied either on drop off or curbside service. It was noted, that using both drop off and curbside services is more efficient than using only one. Roughly 45 per cent of the 
municipalities, employing PAYT program, offers both services, while the 37 per cent offers only one service. Therefore, a suggestion is that offering both services and in combination with PAYT system the air quality might be additionally improved. In PAYT program residents pay only for the amount of trash they generate. Thus, as the residents come to realise that trash disposal costs more than recycling, they may be more likely to recycle and compost more and throw away less. Implementation of a PAYT program, in conjunction with a curbside recycling program, can increase a community's recycling rate between 20 and 27 percent. In addition, PAYT has shown to decrease a community's residential trash generation rate. Furthermore, by diverting waste from disposal and by implementing PAYT programs the life of landfills is extended, the air pollution from trash incinerators, as well as, the need for new disposal facilities is decreased (Bilitewski, 2008; Reichenbach, 2008).

The coefficient of reciprocal program is negative in both estimates and significant at 10 and 5 per cent respectively for fixed effects and SFA fixed effects model. On the other hand the coefficient of the dummy variable regional program is significant only in the case of SFA and has negative but lower effects on air quality. Reciprocal program is coordinated by the county where the municipality belongs, while regional program refer to regional agreements between counties. Thus the results indicate that recycling strategies considered within a reciprocal-county context might improve the air quality more efficiently than regional agreements. More specifically, reciprocal program refers to agreement between municipalities within a county, while regional program refers to agreements between municipalities within two or more counties.

Generally, based on the technical efficiency scores estimated by the SFA model, , are higher for the municipalities which provide PAYT program, both curbside and drop off trash, food and yard collection services and organize the recycling process within a reciprocal program. This can be explained by the following: Firstly, providing both trash collection 
services allows the increases the efficiency score and improves the air quality. In a curbside program, recyclable materials are placed in special containers at the curb for pickup, while in the drop off program citizens can transport and drop off their recyclable materials in a centre. The advantage of curbside program is the high participation rate because it is easy for the citizens to use this system. However, its cost is higher than the cost of the drop off system. On the other hand, drop off system is easy to be implemented, but it is accompanied by low participation rates, because it requires additional effort by the public. Therefore, drop off service can be used as a supplement to the curbside system (Zaman, 2010).

The efficiency scores derived by the SFA estimates suggest that when both curbside and drop off services are provided, are higher improving the air quality. More specifically, when both services are provided for the trash collection the average efficiency score is 0.9127 . Regarding the case where only curbside and only drop off services are provided the average efficiency scores are respectively 0.9074 and 0.8890 . Regarding the yard waste collection the average efficiency scores when both services, only curbside and only drop off service is provided are respectively $0.9217,0.9032$ and 0.8865 . The respective values for food waste collection are $0.9234,0.8874$ and 0.8753 .

Secondly, there are two traditional approaches to disposing of municipal solid waste; a flat-rate system and municipal taxes. Under the flat-rate system there is no link between the actual costs for waste disposal and individual waste production, thus users do not consider the quantity of waste they produce. Regarding the municipal taxes all users pay the same taxes regardless of how much waste they present for pickup. On the other hand, PAYT is a unitpricing or variable pricing system which charges the quantity of waste and it is not fixed. The finding sin this study confirm previous results that PAYT programs are an effective tool in increasing waste separation and recycling, and also encourage waste minimization (Bilitewski, 2008; Batllevell and Hanf, 2008; Reichenbach, 2008). Thus, increasing recycling 
the air quality is improved. Moreover, household waste is "generally positively related to household income so poorer families are likely to face lower waste collection charges under PAYT systems (Batllevell and Hanf, 2008). The average efficiency scores for municipalities with PAYT system and no PAYT system are 0.9065 and 0.8439 respectively, indicating that PAYT is a valuable for encouraging and increasing recycling resulting to air quality improvement.

Finally, the average efficiency score for municipalities which organise the recycling strategies within a reciprocal program is 0.911 . On the other hand the average technical efficiency score is 0.8177 for municipalities which do not participate in reciprocal program, while the respective value for municipalities which do participate in a regional program is 0.8549. Thus, it becomes clear that reciprocal program leads to a higher efficiency regarding the improvement of the air quality. Concluding, SFA allows us to estimate the technical efficiency regarding the air quality and the various inputs examined in this study, such as economic and demographic factors, weather and recycling and waste collection systems.

However, there are application limits and restrictions on the relationship between recycling and air pollution examined in this study. Firstly, additional factor should be considered as waste service costs, traffic density and others, which can be useful for the designation of the optimum recycling rate plan. Furthermore, the relationship between recycling rate and additional air pollutants should be examined, because the pollution emitted from landfills and combustion process is varied on the kind of pollutants and quantity. Furthermore, the relationship between recycling rates and various air pollutants or water pollution separately for each category of products can be examined, as paper, metal, aluminium, glass and plastic among others. The reason is that the recycling process of each product is different, as well as, the air pollution types and levels emitted might be varied. For example, paper recycling causes water pollution, which affect agricultural and fishery 
production, while refineries of metal scrap industry cause air and water pollution. Lead acid batteries recycling is a typical industry causing environmental pollution.

In addition, more attention should be paid on PAYT program, like the relation of its price and fixed price paid in the case where PAYT is absent. In parallel with the PAYT program price and fixed price, the recycling prices and costs, trash delivery costs and generally the solid waste management expenditures should be examined. Also, the availability of hazardous centres and events leads to air quality improvement and environmental efficiency. In parallel with PAYT, it would be very helpful if we could examine and compare the PAYT with fixed prices effects and calculate the marginal willingness to pay (MWTP) for the reduction in air pollution.

Another important drawback of the relationship examined here, is that this study examines the recycling rates on municipality level by aggregating industrial and household recycling. However, it would be useful if the data were allowed us to examine separate the effects of industrial and household recycling on air quality, considering the trash, food and yard services as well as other recycling and economic variables. For example the performance of municipality on recycling it would be useful for researchers and policy makers to adopt appropriate recycling programs. However, these limitations are mentioned to be considered in future research.

\section{Conclusions}

This study proposed a quantification of the relationship between $\mathrm{PM}_{2.5}$ air pollutant and recycling rate. The study sample was the municipalities in the state of Massachusetts and the study period was 2009-2012. A negative relationship between $\mathrm{PM}_{2.5}$ and recycling rate has been found indicating that recycling can lead to air quality improvement. The models control for various factors, as meteorological data, income per capita, dummy variables considering the type of waste among others. In addition, the technical efficiency scores derived by the 
SFA model shows that municipalities which provide both curbside and drop off program, supplemented by PAYT system and organizing recycling strategies through reciprocal program are higher. This analysis can help the municipalities with low efficiency scores to take as an example the more efficient ones, to learn from this experience and to implement similar programs in order to improve air quality. However, this study examines only a local effect in the state of Massachusetts and probably cannot be generalized. More specifically, local conditions, as well as, economic factors including income which increases environmental awareness, can be varied in other states.

This study proposes the examination of recycling rate to additional air pollutants, as $\mathrm{SO}_{2}$, $\mathrm{NO}_{\mathrm{X}}$ and $\mathrm{CO}_{2}$ among others, as well as, the relationship between recycling and water pollution. Additionally, waste service expenditures can be considered, as well as, additional factors, like the education level, the age and other demographic household characteristics can be included into the regression analysis. Therefore, the surveys should be designed in a way that demographic characters, among others, should be considered. For example the research could be focus on whether the more educated, older households who own home or not are recycling more. Another possibility is to examine the relationship between air pollution and recycling rates of specific materials, as paper, steel, aluminium and hazardous products as tires and batteries among others. Furthermore, the examination of the recycling rate and pollution using larger panel data, if these are available, is suggested.

Generally, letting the public know about what happens to the materials once after they have been collected also helps to reinforce individual's interest for the public good and encourages participation. Recycling can be the platform from which many people can be educated about their environment and good citizenship. Municipalities, councils and local authorities should also promote and support waste minimisation schemes. These include the use of home composting, local bring banks and household amenity sites as well as 
opportunities to reduce waste and reuse items where possible. For example, this could include preventing food waste and promoting furniture reuse schemes, local refillable schemes and low packaging shops and markets.

In addition, waste prevention programs can be established in order to encourage businesses to contribute to a more sustainable economy by building waste reduction into design, offering alternative business models and delivering new and improved products and services, as well as, to make business responsible for what they produce, to encourage a culture of valuing resources by making it easier for people and businesses to find out how to reduce their waste, support action by central and local government, businesses and civil society to capitalise on these opportunities. Furthermore, the central authorities in collaboration with local governments in municipalities can work in order to increase the frequency and quality of rubbish collections and make easier for the households to recycle. Another policy could be that local governments can encourage people to recycle more, reduce and re-use their waste by giving them various kinds of rewards.

\section{Annex}

Massachusetts Department of Public Health (http://www.mass.gov/eohhs/gov/departments/dph/).

Massachusetts Department of Environmental Protection (http://www.mass.gov/dep).

Massachusetts Executive Office for Administration and Finance (http://www.mass.gov/anf/research-and-tech).

Massachusetts Department of Revenue (DOR) (http://www.mass.gov/dor/local-officials).

Massachusetts Executive Office of Labor and Workforce Development (http://www.mass.gov/lwd). 


\section{References}

Afonso, A., Fernandes, S., 2008. Assessing and explaining the relative efficiency of local government: evidence for Portuguese municipalities. J. Soc. Econ. 37(5), 1946-1979.

Aigner, DJ., Lovell, CAK., Schmidt, P., 1977. Formulation and Estimation of Stochastic Frontier Production Function Models. J. Econometrics 6(1), 21-37.

Barmpadimos, I., Keller, J., Oderbolz, G., Hueglin, C., Prevot, ASH. One decade of parallel fine $\left(\mathrm{PM}_{2.5}\right)$ and coarse $\left(\mathrm{PM}_{10}-\mathrm{PM}_{2.5}\right)$ particulate matter measurements in Europe: trends and variability. Atmos. Chem. Phys. 12, 3189-3203.

Batllevell, M., Hanf. K. 2008. The fairness of PAYT systems: Some guidelines for decisionmakers. Waste Manage. 28, 2793-2800.

Battese, GE., Coelli, T., 1995. A model for technical inefficiency effects in a stochastic frontier production function for panel data. Empir. Econ. 20, 325-332.

Battese, GE., Corra, GS., 1977. Estimation of a Production Frontier Model: With Application to Pastoral Zone of Eastern Australia. Aust. J. Agr. Econ. 21(3), 169-179.

Beckerman, W., 1992. Economic Growth and the Environment: Whose Growth? Whose Environment? . World Dev. 20(4), 481-496.

Bel, G. Fageda, X., 2010. Empirical analysis of solid management waste costs: Some evidence from Galicia, Spain. Resour. Conserv. Recy. 54(3), 187-193.

Bilitewski, B., 2008. Pay-as-you-throw - A tool for urban waste management. Editorial. Waste Manage. 28, 2759.

Callan, S. J., Thomas, J.M., 1997. The Impact of State and Local Policies on the Recycling Effort. Eastern Econ. J. 23(4), 411-423.

Carson, R.T., Jeon, Y., and McCubbin, D.R., 1997. The relationship between air pollution emissions and income: US Data. Environ. Dev. Econ. 2, 433-450.

Clark, LP., Millet, DB., Marshall, JD., 2011. Air Quality and Urban Form in U.S. Urban Areas: Evidence from Regulatory Monitors. Envir. Sci. Tech. 45, 7028-7035.

Coelli, TJ., 1996. A Guide to FRONTIER Version 4.1: A Computer Program for Stochastic Frontier Production and Cost Function Estimation. Armidale: CEPA Working Paper 96/07, University of New England.

Collins, JN., Downes, BT., 1977. The effect of size on provision of public services: The case of solid waste collection in smaller cities. Urban Affairs Q. 12(3), 333-347.

De Fre R., Wevers M., 1998. Underestimation in dioxin inventories. Organohalogen Compd. $36,17-20$.

De Groot, H., van Heezik, A., Hollanders, D., Felsö, F., 2011. Cost efficiency of waste management in Dutch municipalities, EWEPA Working Paper, School of Management and Governance, University of Twente, The Netherlands.

EPA, 1995. Emissions from Municipal Solid Waste Landfills. Background Information for Final Standards and Guidelines. No. EPA-453/R-94-021. http://www.epa.gov/ttn/atw/landfill/landflpg.html\#TECH.

EPA, 2010. Unit-Based Garbage Charges Create Positive Economic and Environmental Impact. US Environmental Protection Agency.

Farsi, M., Fetz, A., Filippini, M., 2007. Benchmarking and regulation in the electricity distribution sector. CEPE Working Paper No. 54, ETH Zurich, Zurich, Switzerland.

Farrell, M. J., 1957. The Measurement of Productive Efficiency. J.R. Stat.Soc.Ser. A-G. 120(3), 253-290. 
Fishhbein, B. K., 1991. Reducing package waste; Europe takes the fead. In third Annual Recycling conference November 12-13. In: Q A EL-kholy \& M.K Tolba, (Eds). The world environment 1972-1992: Two decades of challenge. London: Chapman and Hall.

Giovanis, E., 2014. The effect of smog-ozone warnings and a vanpool program on traffic volume in York County of South Carolina. Environ. Plann.B, advance online publication, doi:10.1068/b130018p.

Global Alliance for Incinerator Alternatives. (2009). Incinerator: Myths vs. Facts. Retrieved June 2010 from http://www.no-burn.org/downloads/GAIA\%20Incinerator\%20Myths\%20 vs\%20Facts.pdf.

Gordon, C. J., 2003. Role of environmental stress in the physiological response to chemical toxicants. Environ. Res. 92(1), 1-7.

Grossman, GM., Krueger, AB., 1993. Pollution and growth: what do we know? In: Goldin, I., Winters, L. (Eds.), The Economics of Sustainable Development. MIT Press, Cambridge, MA.

Grossman, GM., Krueger, A.B., 1995. Economic growth and the environment. Q. J. Econ. 110 (2), 353-377.

Harrison, RM., Yin, J., 2000. Particulate matter in the atmosphere: which particle properties are important for its effects on health? Sci. Total Environ. 249(1-3), 85-101.

Hirsch, WZ., 1965. Cost functions of an urban government service: refuse collection. Rev. Econ. Stat. 47(1), 87-92.

Kemper, P., Quigley, J. 1976. The Economics of Refuse Collection. Ballinger, Cambridge, MA.

Knox E.G., 2000. Childhood cancers, birthplaces, incinerators and landfill sites. International J. Epidemiol. 29, 391-397.

Kuhn, TP., Schulz, KT., 2003. Recycling for sustainability - a long-run perspective?. Int. J. Glob. Environ. 3, 339-355.

Kumbhakar, SC., 1990. Production Frontiers, Panel Data and Time-Varying Technical Inefficiency, J. Econometrics 46(1/2), 201-212.

Kumbhakar, SC., Lovell, CAK., 1990. Stochastic Frontier Analysis. Cambridge University Press.

Lecoeur, E., Seigneur, C., Terray, L., Pagé, C., 2012. Influence of Climate on $\mathrm{PM}_{2.5}$ Concentrations over Europe : A Meteorological Analysis using a 9-year Model Simulation. Geophys. Res/ Abst. 14, 3976-3984.

Li, N., Kim, S. Wang, M., Froines, J. Siouts, C., Nel, A., 2002. Use of a stratified oxidative stress model to study the biological effects of ambient concentrated and diesel exhaust particulate matter. Inhal. Toxicol. 14, 459-486.

Li, N., Hao, M., Phalen, RF., Hinds, WC., Nel, AE. 2003. Particulate air pollutants and asthma.A paradigm for the role of oxidative stress in PM-induced adverse health effects. Cl. Immunol. 109(3), 250-265.

Meeusen, W., van den Broeck, J., 1977. Efficiency Estimation from Cobb-Douglas Production Functions with Composed Error. Int. Econ. Rev. 18(2), 435-444.

Merrild, H., Larsen, A.W., Christensen, T.H., 2012. Assessing recycling versus incineration of key materials in municipal waste: The importance of efficient energy recovery and transport distances. Waste Manage 32(5), 1009-1018.

Nel, AE., Diaz-Sanchez, D., Ng, D., Hiura, T., Saxon, A. 1998. Enhancement of allergic inflammation by the interaction between diesel exhaust particles and the immune system. J. Allergy Clin. Immun. 102, 539-554.

Panayotou, T., 1997. Environmental Kuznets Curve. Environ. Dev. Econ. 2, 465-484.

Park ,A.K., Hong, Y.C., Kim, H., 2011. Effect of changes in season and temperature on mortality associated with air pollution in Seoul, Korea. J. Epidemiol. Commun. H. 65(4):368-375. 
Peng, R.D., Dominici, F., Pastor-Barriuso, R., Zeger, S.L., Samet, J.M. 2005. Seasonal analyses of air pollution and mortality in 100 U.S. cities. Am. J. Epidemiol. 161(6), 585594.

Reichenbach, J. 2008. Status and prospects of pay-as-you-throw in Europe - A review of pilot research and implementation studies. Waste Manage. 28, 2809-2814.

Robusto, C.C. 1957. The cosine-haversine formula. Amer. Math. Monthly. 64(1), 38-40.

Russell, L. 2011. An Evaluation of Municipal Recycling Programs in Massachusetts. Project Number:IQP-SYS-009, Worcester Polytechnic Institute, Worcester, MA 01609.

Samakovlis, E. 2001. Economics of Paper Recycling: Efficiency, Policies and Substitution Possibilities, Umeå Economic Studies No. 563. Department of Economics, Umea University, Sweden.

Sarnat, JA., Brown, KW., Schwartz, J. Coull, BA. and Koutrakis, P., 2005. Ambient Gas Concentrations and Personal Particulate Matter Exposures: Implications for Studying the Health Effects of Particles. Epidemiology, 16(3), 385-395.

Seaton, A., Godden, D., MacNee, W., Donaldson, K., 1995. Particulate air pollution and acute health effects. Lancet 345(8943), 176-178.

Selden, TM., Song, D., 1994. Environmental Quality and Development: Is There a Kuznets Curve for Air Pollution Emissions? J. Environ. Econ. Manag. 27(2), 147-162.

Shafik, N., Bandyopadhyay, S., 1977. Economic Growth and Environmental Resources. J. Environ. Econ. Manag. 4, 1-24.

Skene, KJ., Gent, JF., McKay, LA., Belanger, K., Leaderer, BP. and Holford, TR. 2010. Modeling effects of traffic and landscape characteristics on ambient nitrogen dioxide levels in Connecticut. Atmos. Environ. 44, 5156-5164.

State Street Trust Company (1922). Boston: One Hundred Years a City. Boston.

Tai, PKA., Mickley, LJ., Jacob, DJ., 2010. Correlations between fine particulate matter $\left(\mathrm{PM}_{2.5}\right)$ and meteorological variables in the United States: Implications for the sensitivity of $\mathrm{PM}_{2.5}$ to climate change. Atmos. Environ. 44, 3976-3984.

Tai, PKA., Mickley, LJ., Jacob, DJ., Leibensperger, EM., Zhang, L., Fisher, JA., Pye, H.O.T. 2012. Meteorological modes of variability for fine particulate matter $\left(\mathrm{PM}_{2.5}\right)$ air quality in the United States: implications for $\mathrm{PM}_{2.5}$ sensitivity to climate change. Atmos. Chem. Phys. 12, 3131-3145.

Verneke, T., Clercq, MD. 2006. The income-environment relationship: evidence from a binary response model. Ecol. Econ. 59, 419-428.

Wiedinmyer, C., Yokelson, R.J., Gullett, B.K., 2014. Global emissions of trace gases, particulate matter, and hazardous air pollutants from open burning of domestic waste. Environ. Sci. Technol. 48(16), 9523-9530.

Wooldridge, J.M., 2002. Econometric analysis of cross section and panel data. The MIT Press: Cambridge, Massachusetts.

Zaman, A.U. 2010. Comparative study of municipal solid waste treatment technologies using life cycle assessment method. Int. J. Environ. Sci. Tech. 7 (2), 225-234. 
Table 1.Summary Statistics

\begin{tabular}{|c|c|c|c|c|c|c|}
\hline Variables & & Period 2009-2012 & Period 2009 & Period 2010 & Period 2011 & Period 2012 \\
\hline \multirow[b]{2}{*}{$\mathrm{PM}_{2.5}\left(\mu \mathrm{g} / \mathrm{m}^{3}\right)^{1}$} & Mean & 8.020 & 8.666 & 8.246 & 7.664 & 7.548 \\
\hline & $\begin{array}{c}\text { Standard } \\
\text { Deviation }\end{array}$ & 0.611 & 0.608 & 0.621 & 0.618 & 0.580 \\
\hline \multirow[b]{2}{*}{ Total Trash Tonnage } & Mean & 5930.131 & $5,023.165$ & $6,196.451$ & $6,544.734$ & $6,385.21$ \\
\hline & $\begin{array}{c}\text { Standard } \\
\text { Deviation }\end{array}$ & $14,474.97$ & $13,752.27$ & $14,429.22$ & $14,972.55$ & $15,157.32$ \\
\hline \multirow[b]{2}{*}{ Recycling Rate } & Mean & 28.635 & 27.075 & 28.156 & 29.335 & 30.153 \\
\hline & $\begin{array}{l}\text { Standard } \\
\text { Deviation }\end{array}$ & 6.257 & 6.882 & 6.704 & 5.949 & 6.297 \\
\hline \multirow{2}{*}{$\begin{array}{c}\text { Income Per Capita ( } 2010 \\
\text { as baseline year) }\end{array}$} & Mean & $35,347.43$ & $32,465.55$ & $35,391.79$ & $36,210.97$ & $37,344.69$ \\
\hline & $\begin{array}{l}\text { Standard } \\
\text { Deviation }\end{array}$ & $8,096.729$ & $8,452.03$ & $8,248.68$ & $7,556.72$ & $7,876.19$ \\
\hline \multirow[b]{2}{*}{ Unemployment Rate } & Mean & 7.238 & 7.827 & 8.057 & 7.079 & 6.588 \\
\hline & $\begin{array}{c}\text { Standard } \\
\text { Deviation }\end{array}$ & 0.973 & 0.856 & 1.051 & 1.038 & 0.921 \\
\hline \multirow[b]{2}{*}{ Average Temperature } & Mean & 12.082 & 9.043 & 13.901 & 14.638 & 10.700 \\
\hline & $\begin{array}{l}\text { Standard } \\
\text { Deviation }\end{array}$ & 5.133 & 1.782 & 4.570 & 5.120 & 1.953 \\
\hline \multirow[b]{2}{*}{ Precipitation } & Mean & $1,253.794$ & $1,233.507$ & $1,311.668$ & $1,385.784$ & $1,078.37$ \\
\hline & $\begin{array}{c}\text { Standard } \\
\text { Deviation }\end{array}$ & 190.605 & 97.681 & 166.563 & 115.894 & 205.823 \\
\hline \multirow[b]{2}{*}{ Wind Speed } & Mean & 13.009 & 12.381 & 14.261 & 13.625 & 11.698 \\
\hline & $\begin{array}{c}\text { Standard } \\
\text { Deviation }\end{array}$ & 3.496 & 2.864 & 3.541 & 4.096 & 2.670 \\
\hline
\end{tabular}

$\mathrm{PM}_{2.5}$ is measured in micrograms per cubic meter $\left(\mu \mathrm{g} / \mathrm{m}^{3}\right)$, total trash tonnage in tonnes, temperature in fahrenheit, precipitation in in inches per 24-hour, wind speed in miles per hour (mph). 
Table 2. Correlation matrix

\begin{tabular}{|c|c|c|c|c|c|}
\hline & $\mathrm{PM}_{2.5}$ & $\begin{array}{c}\text { Total Trash } \\
\text { Tonnage }\end{array}$ & $\begin{array}{c}\text { Recycling } \\
\text { Rate }\end{array}$ & $\begin{array}{c}\text { Income Per } \\
\text { Capita }\end{array}$ & $\begin{array}{c}\text { Unemployment } \\
\text { Rate }\end{array}$ \\
\hline $\begin{array}{c}\text { Total Trash } \\
\text { Tonnage }\end{array}$ & $\begin{array}{c}0.0428 \\
(0.3113)\end{array}$ & & & & \\
\hline Recycling Rate & $\begin{array}{c}-0.1811 \\
(0.0000)^{* * *}\end{array}$ & $\begin{array}{c}-0.1406 \\
(0.0000)^{* * *}\end{array}$ & & & \\
\hline $\begin{array}{c}\text { Income Per } \\
\text { Capita }\end{array}$ & $\begin{array}{c}-0.1195 \\
(0.0000)^{* * *}\end{array}$ & $\begin{array}{c}-0.0697 \\
(0.0299)^{* *}\end{array}$ & $\begin{array}{c}0.2598 \\
(0.0000)^{* * *}\end{array}$ & & \\
\hline $\begin{array}{c}\text { Unemployment } \\
\text { Rate }\end{array}$ & -0.0785 & -0.0886 & -0.1917 & -0.4066 & \\
\hline $\begin{array}{c}\text { Population } \\
\text { Density }\end{array}$ & $-0.0054)^{* * *}$ & $(0.0058)^{* * *}$ & $(0.0000)^{* * *}$ & $(0.0000)^{* * *}$ & \\
\hline
\end{tabular}

p-values in brackets, $* * *$ and $* *$ denote significance at $1 \%$ and $5 \%$ level 
Table 3. Source and types of solid waste

\begin{tabular}{|c|c|c|}
\hline Source & Typical waste generators & Types of solid wastes \\
\hline Residential & $\begin{array}{l}\text { Single and multifamily } \\
\text { dwellings }\end{array}$ & $\begin{array}{l}\text { Food wastes, paper, } \\
\text { cardboard, plastics, textiles, } \\
\text { leather, yard wastes, wood, } \\
\text { glass, metals, ashes, special } \\
\text { wastes (e.g., bulky items, } \\
\text { consumer electronics, white } \\
\text { goods, batteries, oil, tires), } \\
\text { and household hazardous } \\
\text { wastes.). }\end{array}$ \\
\hline Industrial & $\begin{array}{l}\text { Light and heavy } \\
\text { manufacturing, fabrication, } \\
\text { construction sites, power } \\
\text { and chemical plants. }\end{array}$ & $\begin{array}{l}\text { Housekeeping wastes, } \\
\text { packaging, food wastes, } \\
\text { construction and demolition } \\
\text { materials, hazardous wastes, } \\
\text { ashes, special wastes. }\end{array}$ \\
\hline Commercial & $\begin{array}{l}\text { Stores, hotels, restaurants, } \\
\text { markets, office buildings, } \\
\text { etc. }\end{array}$ & $\begin{array}{l}\text { Paper, cardboard, plastics, } \\
\text { wood, food wastes, glass, } \\
\text { metals, special wastes, } \\
\text { hazardous wastes. }\end{array}$ \\
\hline Institutional & $\begin{array}{l}\text { Schools, hospitals, prisons, } \\
\text { government centers. }\end{array}$ & Same as commercial. \\
\hline $\begin{array}{l}\text { Construction and } \\
\text { demolition }\end{array}$ & $\begin{array}{l}\text { New construction sites, road } \\
\text { repair, renovation sites, } \\
\text { demolition of buildings }\end{array}$ & $\begin{array}{l}\text { Wood, steel, concrete, dirt, } \\
\text { etc. }\end{array}$ \\
\hline Municipal services & $\begin{array}{l}\text { Street cleaning, landscaping, } \\
\text { parks, beaches, other } \\
\text { recreational areas, water and } \\
\text { wastewater treatment plants. }\end{array}$ & $\begin{array}{l}\text { Street sweepings; landscape } \\
\text { and tree trimmings; general } \\
\text { wastes from parks, beaches, } \\
\text { and other recreational areas; } \\
\text { sludge. }\end{array}$ \\
\hline $\begin{array}{l}\text { Process (manufacturing, } \\
\text { etc.) }\end{array}$ & $\begin{array}{l}\text { Heavy and light } \\
\text { manufacturing, refineries, } \\
\text { chemical plants, power } \\
\text { plants, mineral extraction } \\
\text { and processing. }\end{array}$ & $\begin{array}{l}\text { Industrial process wastes, } \\
\text { scrap materials, off- } \\
\text { specification products, slay, } \\
\text { tailings. }\end{array}$ \\
\hline Agriculture & $\begin{array}{l}\text { Crops, orchards, vineyards, } \\
\text { dairies, feedlots, farms. }\end{array}$ & $\begin{array}{l}\text { Spoiled food wastes, } \\
\text { agricultural wastes, } \\
\text { hazardous wastes (e.g., } \\
\text { pesticides). }\end{array}$ \\
\hline
\end{tabular}

Source: Massachusetts Department of Environmental Protection website (http://www.mass.gov/eea/agencies/massdep/) 
Table 4. Standard volume-to-weight conversion factors for a sample of products

\begin{tabular}{|c|c|c|c|c|c|}
\hline Product & Volume & $\begin{array}{c}\text { Weight } \\
\text { (lbs) }\end{array}$ & Product & Volume & $\begin{array}{c}\text { Weight } \\
\text { (lbs) }\end{array}$ \\
\hline \multicolumn{3}{|c|}{ Panel A: Paper } & \multicolumn{3}{|c|}{ Panel D: Aluminum } \\
\hline Books, hardback, loose & 1 cubic yard & 529.29 & Aluminum foil, loose & 1 cubic yard & 48.1 \\
\hline Books, paperback, loose & 1 cubic yard & 427.5 & Aluminum scrap, cubed & 1 cubic yard & 424 \\
\hline Newspapers & $12 "$ stack & 35 & Aluminum scrap, whole & 1 cubic yard & 175 \\
\hline \multicolumn{3}{|c|}{ Panel B: Plastic } & \multicolumn{3}{|c|}{ Panel E: Ferrous Metals } \\
\hline PETE, 2 liter & 1 bottle & 0.13 & Metal scrap & 55 gallon & 226.5 \\
\hline Beverage container & $12 \mathrm{oz}$. & 0.05 & Metal, car bumper & 1 cubic yard & 906 \\
\hline \multicolumn{3}{|c|}{ Panel C: Glass } & \multicolumn{3}{|c|}{ Panel F: Food } \\
\hline Glass, broken & 1 cubic foot & $80-100$ & Bread, bulk & 1 cubic foot & 18 \\
\hline Glass, broken & 1 cubic yard & $2,160.00$ & Fat & 1 cubic foot & 57 \\
\hline Glass, crushed & 1 cubic foot & $40-50.0$ & Fish, scrap & 1 cubic foot & $40-50$ \\
\hline Glass, plate & 1 cubic foot & 172 & Meat, ground & 1 cubic foot & $50-55$ \\
\hline Window & 1 cubic foot & 157 & Oil, olive & 1 cubic foot & 57.1 \\
\hline
\end{tabular}

Sources: Massachusetts Department of Environmental Protection website (http://www.mass.gov/eea/agencies/massdep/), US Environmental Protection Agency (EPA) http://www.epa.gov/smm/wastewise 
Table 5.Regression Estimates of equations (2) and (3) using Fixed Effects and Stochastic Frontier Analysis with Fixed Effects

\begin{tabular}{|c|c|c|c|c|c|}
\hline Variables & $\begin{array}{l}\text { Fixed Effects } \\
\text { Estimates }\end{array}$ & $\begin{array}{c}\text { SFA with } \\
\text { Time-Varying } \\
\text { Inefficiencies } \\
\text { and Fixed } \\
\text { Effects } \uparrow \\
\end{array}$ & Variables & $\begin{array}{l}\text { Fixed Effects } \\
\text { Estimates }\end{array}$ & $\begin{array}{c}\text { SFA with } \\
\text { Time-Varying } \\
\text { Inefficiencies } \\
\text { and Fixed } \\
\text { Effects } \dagger \\
\end{array}$ \\
\hline Recycling Rate & $\begin{array}{c}-0.0238 \\
(0.0087)^{* * *}\end{array}$ & $\begin{array}{c}-0.0272 \\
(0.0124) * * \\
\end{array}$ & PAYT & $\begin{array}{c}-0.0265 \\
(0.0081)^{* * *}\end{array}$ & $\begin{array}{c}-0.0313 \\
(0.0118)^{* * *} \\
\end{array}$ \\
\hline $\begin{array}{l}\text { Total Trash } \\
\text { Tonnage }\end{array}$ & $\begin{array}{c}0.0042 \\
(0.0018)^{* *}\end{array}$ & $\begin{array}{c}0.0054 \\
(0.0025)^{* *}\end{array}$ & $\begin{array}{l}\text { Reciprocal } \\
\text { Program }\end{array}$ & $\begin{array}{c}-0.0374 \\
(0.0191)^{*}\end{array}$ & $\begin{array}{c}-0.0265 \\
(0.0121)^{* *}\end{array}$ \\
\hline Population Density & $\begin{array}{c}-0.0252 \\
(0.0124)^{* *} \\
\end{array}$ & $\begin{array}{c}-0.0274 \\
(0.0103)^{* * *}\end{array}$ & $\begin{array}{l}\text { Regional } \\
\text { Program }\end{array}$ & $\begin{array}{c}0.0254 \\
(0.0229) \\
\end{array}$ & $\begin{array}{c}-0.0055 \\
(0.00246)^{* *}\end{array}$ \\
\hline Income Per Capita & $\begin{array}{c}0.986 \\
(0.354)^{* * *}\end{array}$ & $\begin{array}{c}0.983 \\
(0.324)^{* * *}\end{array}$ & $\begin{array}{c}\text { Dummy: Trash } \\
\text { Collection } \\
\text { Service (2) }\end{array}$ & $\begin{array}{c}0.121 \\
(0.159)\end{array}$ & $\begin{array}{c}-0.196 \\
(0.032)^{* * *}\end{array}$ \\
\hline $\begin{array}{c}\text { Income Per Capita } \\
\text { Square }\end{array}$ & $\begin{array}{c}-0.0491 \\
(0.0242)^{* *}\end{array}$ & $\begin{array}{c}-0.0489 \\
(0.0121)^{* *}\end{array}$ & $\begin{array}{c}\text { Dummy: Trash } \\
\text { Collection } \\
\text { Service (3) }\end{array}$ & $\begin{array}{c}-0.059 \\
(0.021)^{* * *}\end{array}$ & $\begin{array}{c}-0.0199 \\
(0.0014)^{* * *}\end{array}$ \\
\hline $\begin{array}{l}\text { Unemployment } \\
\text { Rate }\end{array}$ & $\begin{array}{c}-0.0993 \\
(0.0337)^{* * *}\end{array}$ & $\begin{array}{c}-0.0982 \\
(0.0372)^{* * *}\end{array}$ & $\begin{array}{c}\text { Dummy: Yard } \\
\text { Collection } \\
\text { Service (1) }\end{array}$ & $\begin{array}{c}-0.049 \\
(0.027)^{*}\end{array}$ & $\begin{array}{c}-0.0158 \\
(0.009)^{* * *}\end{array}$ \\
\hline $\begin{array}{c}\text { Average } \\
\text { Temperature }\end{array}$ & $\begin{array}{c}0.751 \\
(0.224)^{* * *}\end{array}$ & $\begin{array}{c}0.783 \\
(0.241)^{* * *}\end{array}$ & $\begin{array}{c}\text { Dummy: Yard } \\
\text { Collection } \\
\text { Service (2) }\end{array}$ & $\begin{array}{c}0.0413 \\
(0.0247)^{*}\end{array}$ & $\begin{array}{c}0.0806 \\
(0.021)^{* * *}\end{array}$ \\
\hline $\begin{array}{l}\text { Minimum } \\
\text { Temperature }\end{array}$ & $\begin{array}{c}-0.889 \\
(0.234)^{* * *}\end{array}$ & $\begin{array}{c}-0.921 \\
(0.429)^{* *}\end{array}$ & $\begin{array}{c}\text { Dummy: Yard } \\
\text { Collection } \\
\text { Service (3) }\end{array}$ & $\begin{array}{c}0.043 \\
(0.038)\end{array}$ & $\begin{array}{c}0.037 \\
(0.072)\end{array}$ \\
\hline $\begin{array}{l}\text { Maximum } \\
\text { Temperature }\end{array}$ & $\begin{array}{c}0.806 \\
(0.262)^{* * *}\end{array}$ & $\begin{array}{c}0.887 \\
(0.368)^{* *}\end{array}$ & $\begin{array}{c}\text { Dummy: Food } \\
\text { Collection } \\
\text { Service (1) } \\
\end{array}$ & $\begin{array}{c}-0.196 \\
(0.054)^{* * *}\end{array}$ & $\begin{array}{c}-0.0315 \\
(0.0025)^{* * * *}\end{array}$ \\
\hline Precipitation & $\begin{array}{c}-0.188 \\
(0.0266)^{* * *}\end{array}$ & $\begin{array}{c}-0.0289 \\
(0.0134)^{* *}\end{array}$ & $\begin{array}{c}\text { Dummy: Food } \\
\text { Collection } \\
\text { Service (2) }\end{array}$ & $\begin{array}{c}-0.076 \\
(0.042)^{*}\end{array}$ & $\begin{array}{c}-0.0089 \\
(0.0034)^{* * *}\end{array}$ \\
\hline Wind Speed & $\begin{array}{c}-0.138 \\
(0.0685)^{* *}\end{array}$ & $\begin{array}{c}-0.169 \\
(0.0267)^{* * * *}\end{array}$ & $\begin{array}{c}\text { Dummy: Food } \\
\text { Collection } \\
\text { Service (3) } \\
\end{array}$ & $\begin{array}{l}-0.0058 \\
(0.0479)\end{array}$ & $\begin{array}{c}-0.0091 \\
(0.0022)^{* * *}\end{array}$ \\
\hline No. observations & 1,116 & 1,116 & & & \\
\hline R-square & 0.2866 & & & & \\
\hline Hausman test & $\begin{array}{l}103.85 \\
{[0.000]} \\
\end{array}$ & & & & \\
\hline Log-Likelihood & & 986.364 & & & \\
\hline Wald chi square & & $\begin{array}{l}486.07 \\
{[0.000]}\end{array}$ & & & \\
\hline
\end{tabular}

Standard errors clustered at municipality level are between brackets, ***, ** and * denote significance at $1 \%, 5 \%$ and $10 \%$ level.

The following variables are included in regression estimates, Landfill, Municipality Type. But are not presented as are time invariant 
Figure 1. Scatter plot of recycling rates and $\mathrm{PM}_{2.5}$

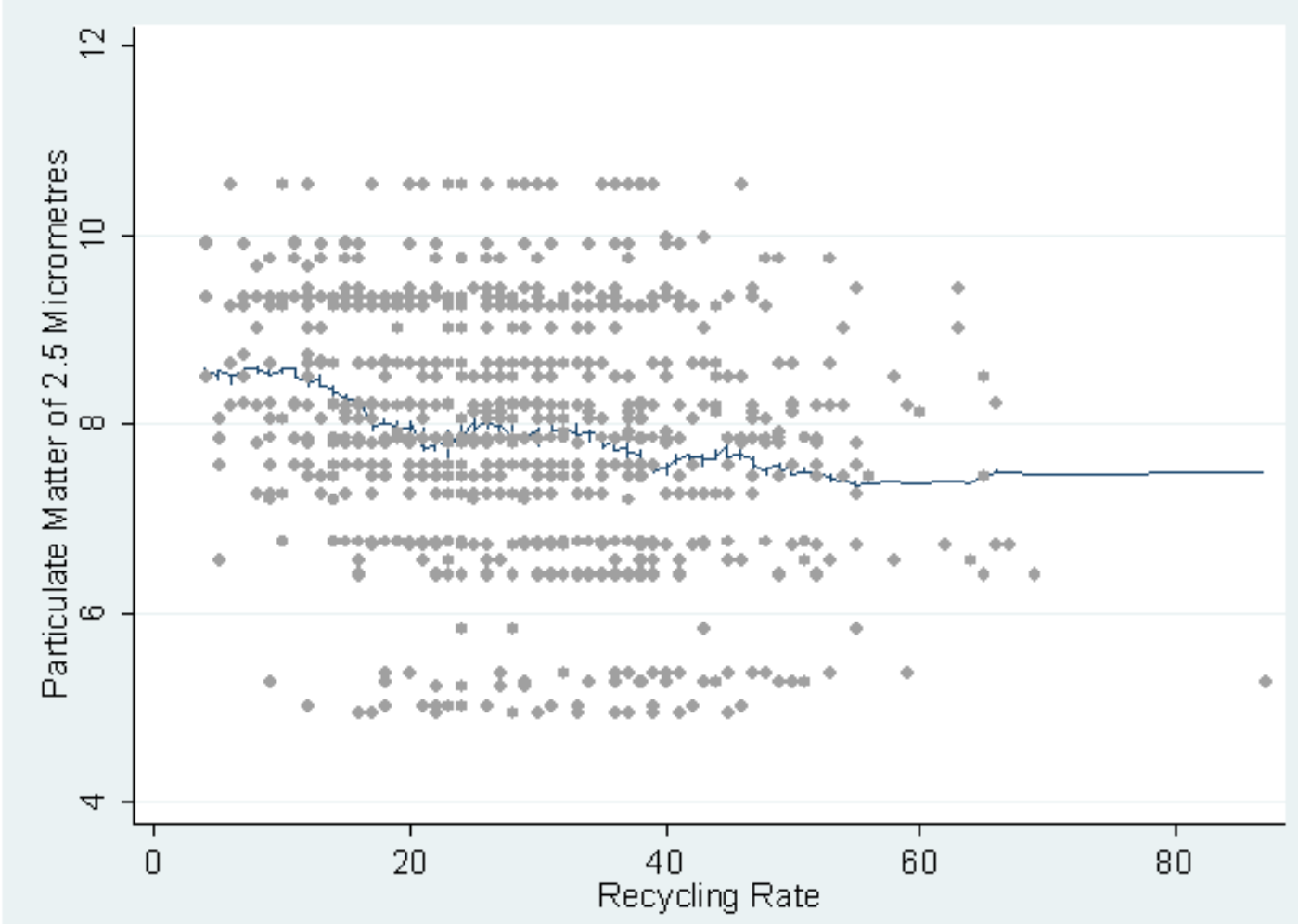

Figure 2. Cross-Section and Panel Data Estimators when there is Unobserved Heterogeneity

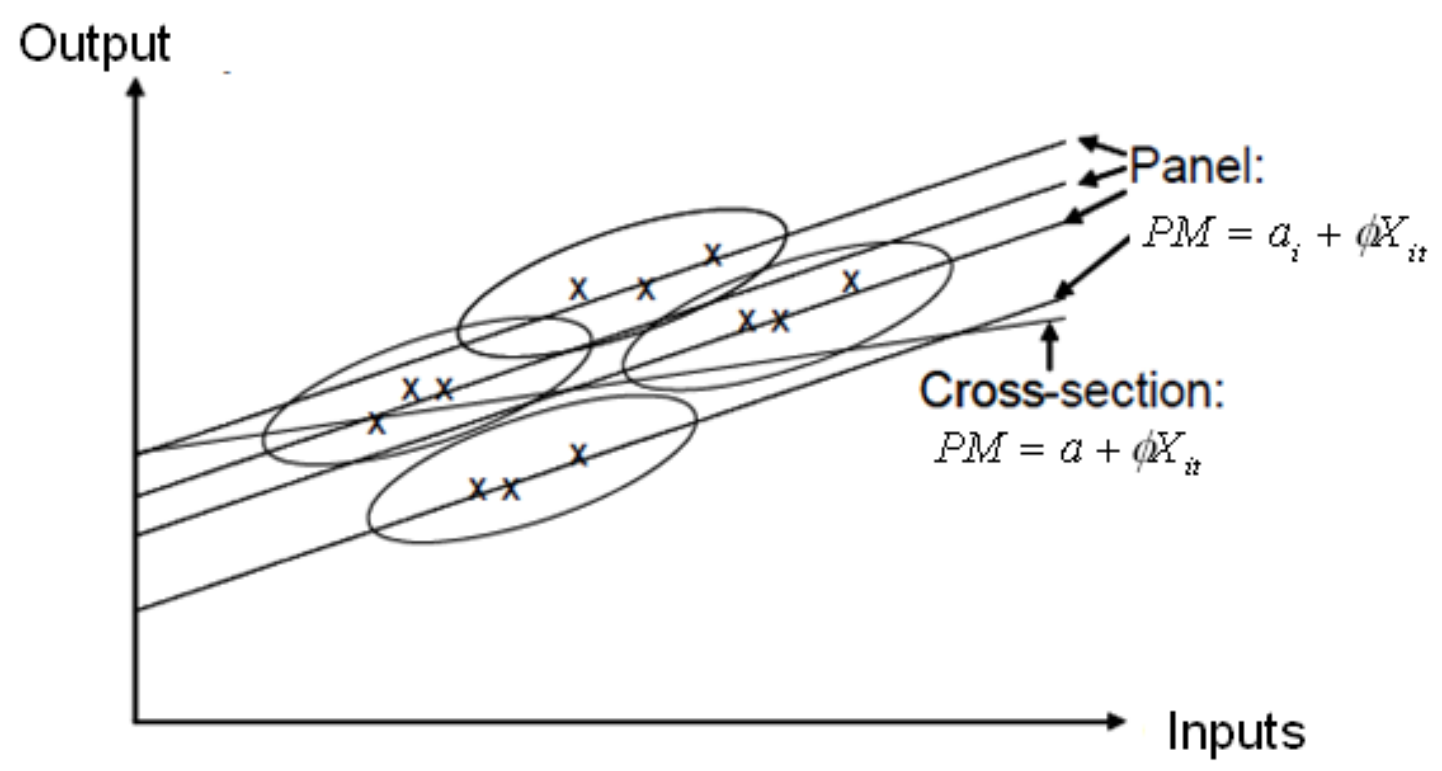


Figure 3. Measure of technical and allocative efficiency

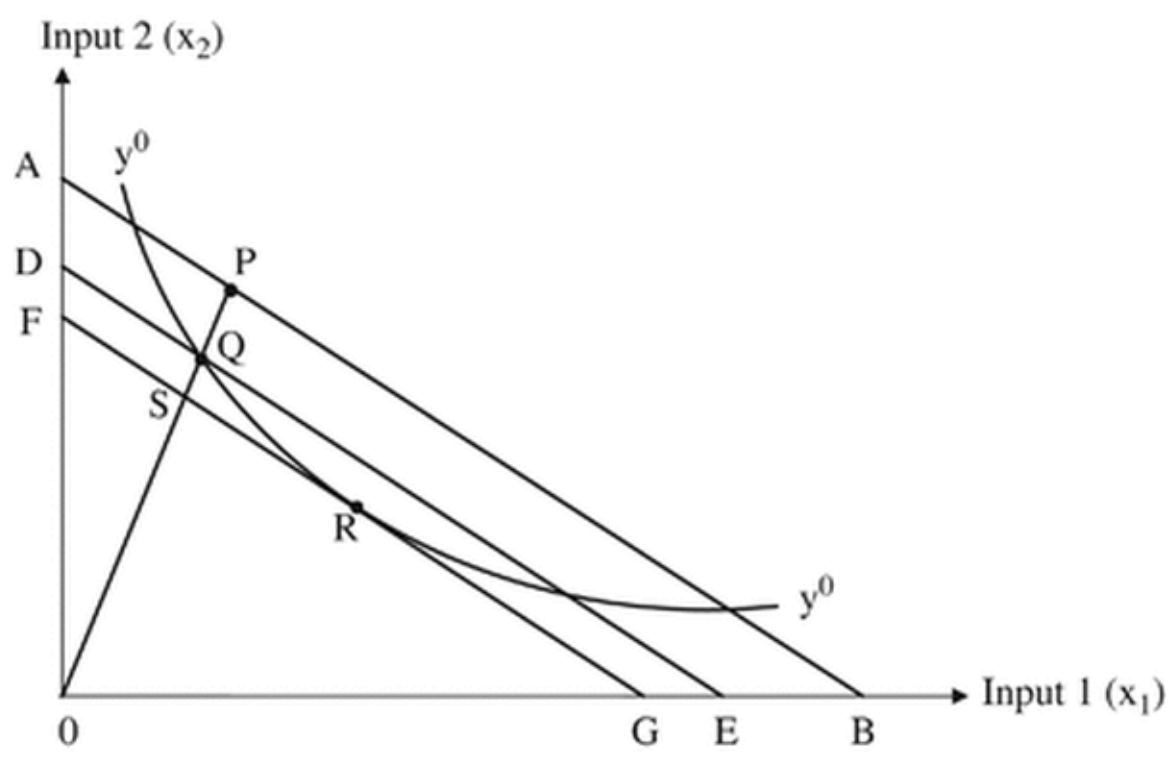

Figure 4.Technical Efficiency

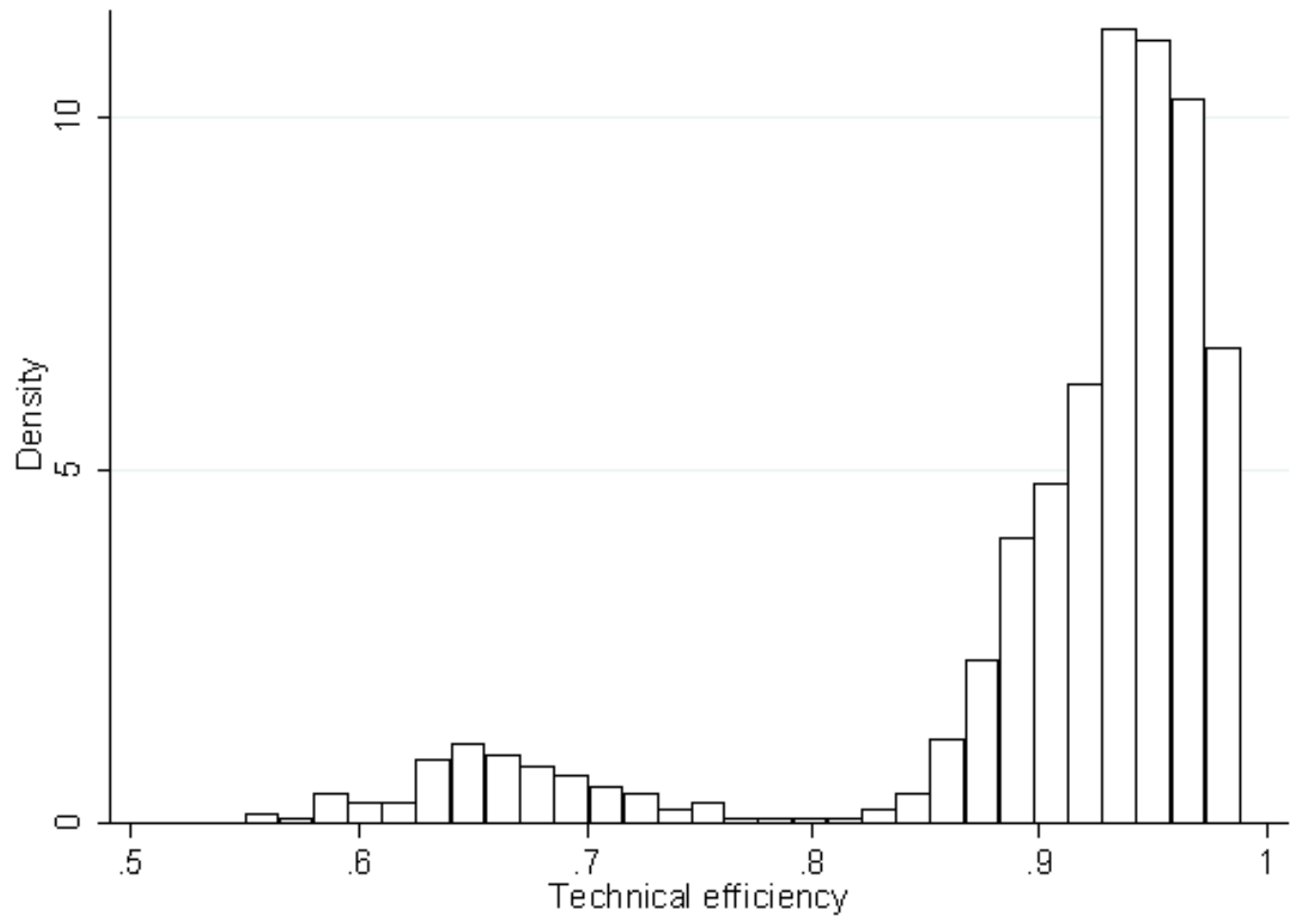

